\title{
Analysis of the real estate market in the city of Lublin (Poland) from the perspective of spatial development
}

\author{
Patrycja Pochwatka ${ }^{1, *}$ \\ ${ }^{1}$ University of Life Sciences in Lublin, Department of Environmental Engineering and Geodesy, Leszczyńskiego 7, 20-069 Lublin, \\ Poland
}

\begin{abstract}
Real estate, in modern times, is exclusive merchandise, because it is in limited supply and is relatively high-priced compared with goods such as food, clothing, luxury goods. Properly conducted spatial planning can bring measurable benefits to both citizens and investors. This study aims to explore the directions of spatial development in the city of Lublin through an analysis of undeveloped properties sold over a study period of twenty-one months. The main objective of the study was to assess the conditions of spatial development in the city. Data from the Register of Prices and Values for Real Estates were analyzed and visualized cartographically. The number of sales of real property located on the outskirts of the city was far larger than for property situated in the central part of the area studied. During the analyzed period, a total area of $0.8895 \mathrm{~km}^{2}$ of land was sold in Lublin, which represents about $0.6 \%$ of the entire city area. Vast areas were sold in the districts located on the outskirts. Unsurprisingly, the smallest percentage of land was sold in the central part of the city. The trends observed on the undeveloped real estate market are helpful in assessing the level of suburbanization or urban-sprawl. Besides, the usefulness of cartographic methods for real estate market studies was stressed.
\end{abstract}

\section{Introduction}

In cities, the course of spatial development depends mostly on local government laws [1]. Resolutions made with respect to local spatial management plans affect the behaviour of entities participating in the real estate market [2]. For instance, for housing developers, it is crucial whether they can easily build up a plot or whether they have to wait for a zoning approval. Individual buyers, beside spatial planning resolutions, pay much attention to the localization of the property, the neighborhood, and the shape of the plot [3]. In consumer society, the essential factors that influence decision making are local trends or even fashions [4-5].

Real estate, in modern times, is exclusive merchandise, because it is in limited supply and is relatively high-priced compared with goods such as food, clothing, luxury goods, etc. The allocation of resources is a classic market mechanism, so in this specific context, a decision to purchase real estate is determined by its price [6-7]. This interpretation of the market mechanism leads to a large simplification, though. It should be pointed out that the real estate market is a complex set of conditions, where price is not the only thing that matters [8-9]. The functioning and development of the real estate market is affected by several groups of factors including social, macroeconomic, demographic and legal factors as well as those related to the structure of ownership of real property [10-14]. Local authorities mostly focus on economic motives while planning the tactics of spatial development [15]. Looking through the prism of taxes, they want to attract new residents to undeveloped areas, which is why development of residential areas is the main focus of local planning strategies [16]. An absence of relevant regulations leads to inappropriate level of spatial development in cities [17] and sustainable development in rural areas [18-20]. Maps are extremely useful in visualizing space-related data [7, 21-22]. Real estate data is this kind of data because the properties are located in space.

This study aims to explore the directions of spatial development in the city of Lublin through an analysis of undeveloped properties sold over a study period of twenty-one months. The main research questions are the following: Does local spatial planning have an impact on the real estate market in Lublin? Are there any local trends associated with suburbanization?

\section{Study area}

The area encompassed by the study (Fig. 1.) was the city of Lublin (Poland) - a city with county rights and the capital of the Lublin Voivodeship. The city covers a surface area of $147.5 \mathrm{~km}^{2}$ and is divided into 27 districts, 74 geodetic bounds and 8 planning areas. Lublin has a population of 321065 citizens [23] and is the largest agglomeration centre on the right bank of the Vistula river. Historically, the process of settlement in Lublin was determined mostly by natural conditions such as terrain, layout of the river network and distribution of fertile soil. In the last century, changes in the

Corresponding author: patrycja.pochwatka@up.lublin.pl 
administrative boundaries of the city have been caused by population growth, an enlargement of recreational areas and the need for new land for construction sites [24]. Till the late 1950s, the city had expanded territorially in a southerly direction. The most significant spatial development took place in 1959 when the area of the city was expanded two-fold, from $43.70 \mathrm{~km}^{2}$ to 93.18 $\mathrm{km}^{2}$ [25]. In connection with the mass influx of people, the city had to incorporate new areas for residential and industrial construction. Thus, new districts in so far sparsely inhabited areas were formed: the housingcooperative districts, today known as LSM, Czuby, Kalinowszczyzna, Czechów, and Tatary and housing estate districts such as Sławinek. In the early 1970s, due to the lack of recreational areas, an artificial reservoir was built. Its location, southwest of the city on the river Bystrzyca led to the inclusion of these areas, as well as parts of neighboring villages and forest in the administrative boundaries of the city. The prospect of further development and the political and economic transformation at the end of the $20^{\text {th }}$ century were the cause of the most recent expansion of city boundaries in 1989. The rapid development of housing construction caused the establishment of new residential districts with multi-family housing and exclusive residential housing on agricultural land located primarily on the western and northern outskirts of Lublin [26]. Nowadays, the administrative boundaries of the city are stable and fixed, but the global trends suggest that further territorial development associated with suburbanization is possible.

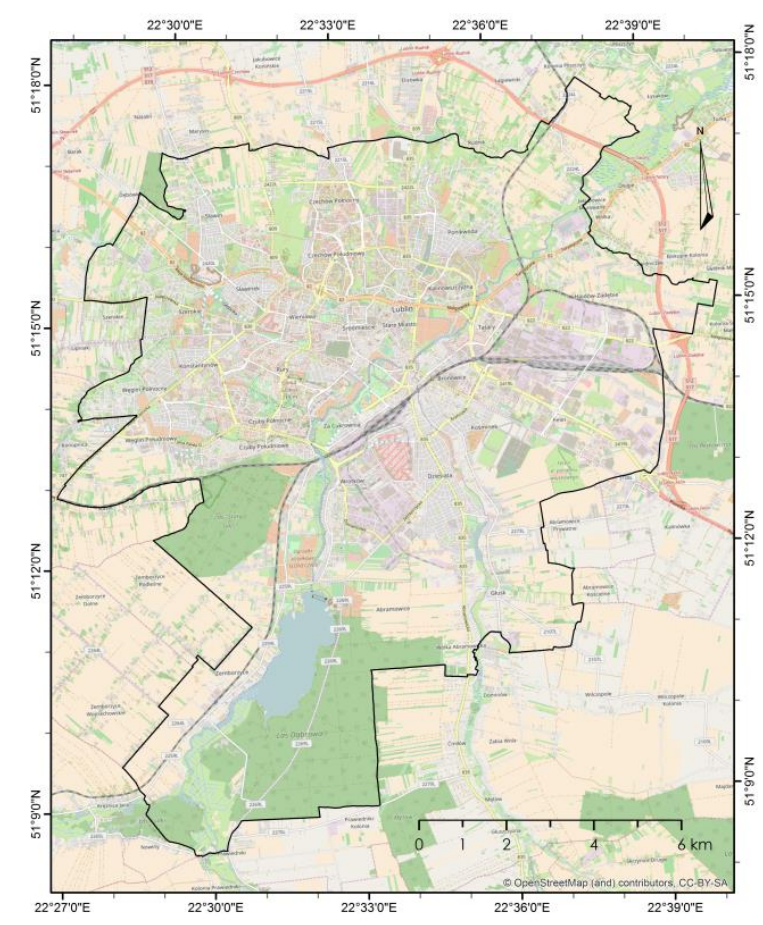

Fig. 1. The city of Lublin (localization and urban development)

Source: Own elaboration based on a reference map retrieved from OpenStreetMap (C) OpenStreetMap authors, Open Database Licence CC-BY-SA)

\section{Materials and methods}

The basic research data were transactions of undeveloped real properties in the cadastral unit of the city of Lublin. The analysis covered a period of twenty one months (from January 2014 to October 2015). The data were obtained from the Register of Real Estate Prices and Values in the GML file format. A database was created in MS Excel, by combining appropriate object classes according to the aforementioned application scheme included in the specification of the conceptual data model for the register. Detailed information on each transaction which was considered useful for market research was included in the analysis, among others the location of the property (address of the parcel), cadastral area of the parcel, type of property and information on type of land use designation as specified in the local spatial plan. A database of coverage of the city with Local Spatial Management Plans helped depict the dependence of the number of properties sold on the area in which they were located. Public access data, such as boundaries of the city and the administrative districts retrieved from the State Registry of Plot Boundaries were used to visualize results. OpenStreetMap (CC-BYSA licensed) served as a background map.

Real estate market data were represented using cartographic methods. By dint of spatial reference of the real estates, it was possible to display real estate data in the individual districts of the city. Bar chart maps showing the total and average area of land sold in the respective districts were prepared. All maps were created using GIS software - ArcGIS 10.3.

\section{Results}

\subsection{Spatial planning}

The coverage of Lublin by spatial plans and the locations of the analyzed real properties sold are shown in Figure 2. A distinct lack of plans in the southern and southeastern part of the city is visible. A majority of the plans regarding this part of the city are currently in preparation. The limited coverage of these areas by plans is directly related to their land use designations - forests (the forest complexes Dąbrowa and Stary Gaj), land under water (Lake Zemborzycki), as well as agricultural land. In such areas, spatial plan regulations are enacted much less frequently than in strongly urbanized areas. Large number of areas without a spatial plan were incorporated in the administrative boundaries of the city in 1975 (for recreation) and 1989 (prospect of further development of the south-eastern part of the city). Worth stressing here is the fact that in recent years the process of spatial planning in Lublin has greatly accelerated even though since 2005 the drafting and maintaining of city plans is not mandatory.

Municipal authorities see it as their priority to organize the space in the centre of the city - the area of Podzamcze, as well as the area of the Main Train Station. The largest area to be covered by the plans that are being prepared is the Ecological System of Protected Areas around river valleys. 


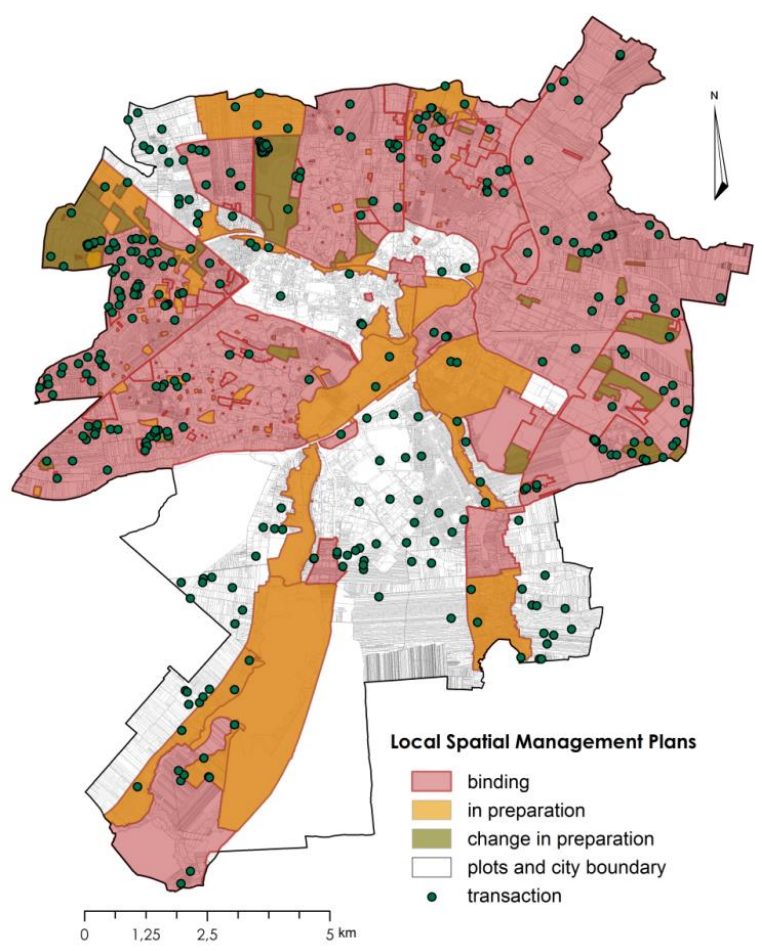

Fig. 2. Local Spatial Management Plans (as of end 2016) with transactions of sale of undeveloped real estate in the city of Lublin

Source: Own elaboration

Essentially, the process of spatial planning in Lublin can be divided into four stages, starting with a lack of a plan (i), a plan ,in preparation” (ii), a binding plan (iii), and eventually the possibility of change - a revision in preparation (iv). Table 1 shows the advancing of the planning stages - the surface area covered and the percentage of coverage. The data indicate that nearly a third of the city area is not covered by local plans. However, it must be pointed out that a substantial part of these areas are woodlands and agricultural land.

Table 1. Local Spatial Management Plans in the city of Lublin.

\begin{tabular}{|c|c|c|}
\hline $\begin{array}{c}\text { Local Spatial Management } \\
\text { Plans }\end{array}$ & $\begin{array}{c}\text { Area } \\
\mathbf{k m}^{\mathbf{2}}\end{array}$ & $\begin{array}{c}\text { Coverage } \\
\mathbf{\%}\end{array}$ \\
\hline Binding & 69.45 & 47.09 \\
\hline In preparation & 23.25 & 15.77 \\
\hline Change in preparation & 6.50 & 4.41 \\
\hline No plan & 48.27 & 32.73 \\
\hline Total & $\mathbf{1 4 7 . 4 7}$ & $\mathbf{1 0 0 . 0 0}$ \\
\hline
\end{tabular}

Source: Own elaboration based on the data come from a database of coverage of the city with Local Spatial Management Plans

\subsection{Acreage of properties sold}

Not only the type and land use designation of undeveloped properties affect their subsequent development. Another important factor is their size. Plots with large acreages located within the city limit have an investment potential as space for the construction of multiple dwellings or other large buildings. Areas of this kind are very difficult to find in city centers. Usually those properties are located on the outskirts. Land use designation of a property is crucial when a plot is to be developed. For agricultural property or property not encompassed by a local plan, a zoning approval has to be obtained in order to develop the plot. For plots located within the administrative boundaries of cities, this procedure is not as complicated as in rural areas. During the analyzed period, a total area of 0.8895 $\mathrm{km}^{2}$ of land was sold in Lublin (Fig. 3.), which represents about $0.6 \%$ of the entire city area. Vast areas were sold in the districts of Felin, Wrotków, Weglin Południowy, Hajdów-Zadębie and Czechów Północny. In these five districts alone, $63 \%$ of total purchases were reported. In other districts, located on the outskirts, the result were not so impressive, although still a substantial percentage of properties were sold there. Unsurprisingly, the smallest percentage of land was sold in the central part of the city.

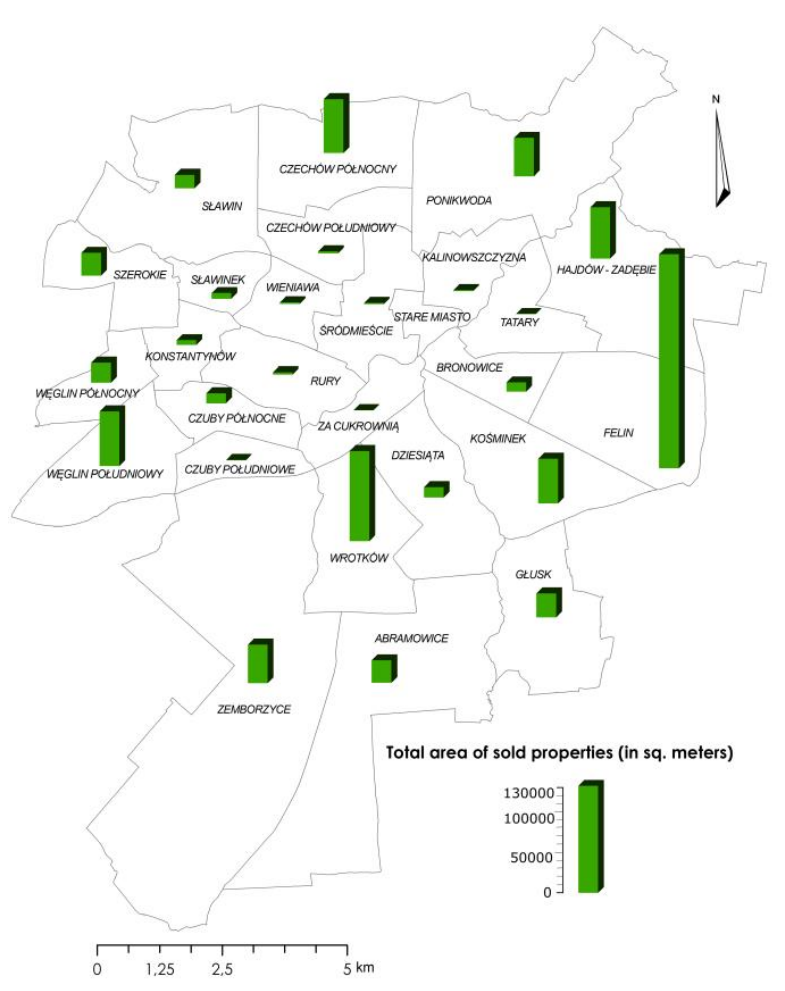

Fig. 3. Total area of sold properties.

Source: Own elaboration

Taking into consideration the average acreage of the properties sold (Fig. 4.), the city is split into three sections: the western section (i), the north-east-south strip (ii) and the central section (iii). In districts of the western section (i), the mean area of estates sold corresponds to an average size of a plot for single-family housing. This group can also be taken to include the district Dziesiąta - famous for its detached housing. 
Districts surrounding the town from the north, east, and south (ii), witness an intensive growth of multi-family housing. This section of the city also includes the district Węglin Południowy, where a large percentage of transactions regarding properties designated for multifamily housing were registered. It is also worth stressing that a considerable amount of land was sold in the district of Felin, which is located in the Special Economic Zone EURO-PARK MIELEC. Due to a scarcity of sites for new investments, the average area of properties sold in the central (iii) districts was small.

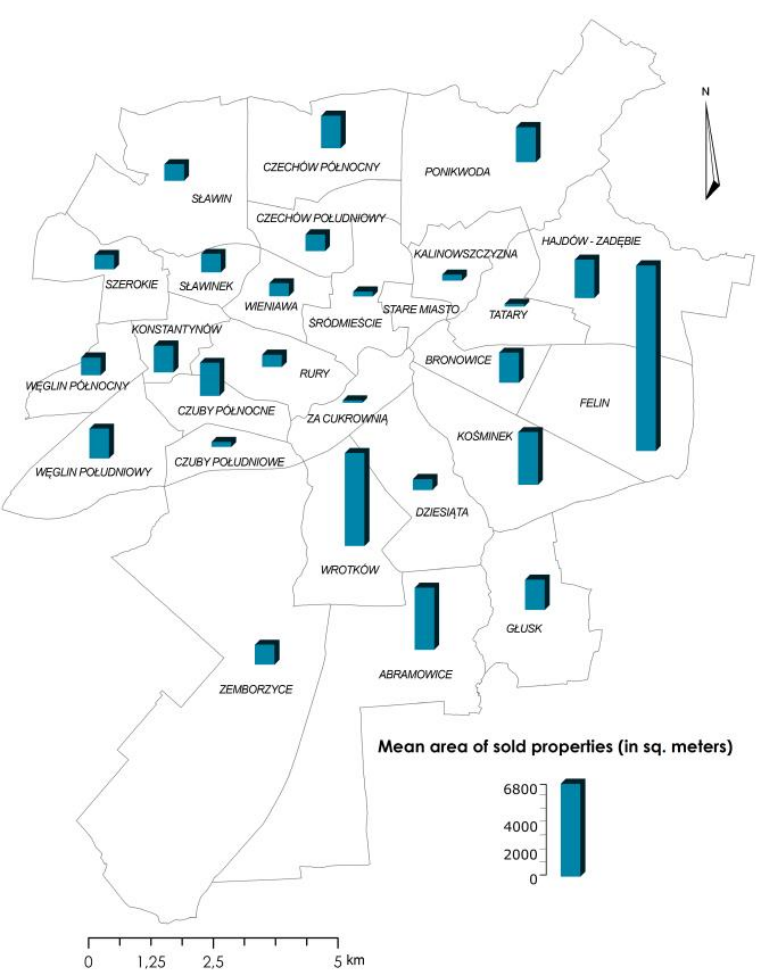

Fig.4. Mean area of sold properties.

Source: Own elaboration

\section{Summary and conclusions}

The trends observed on the undeveloped real estate market are helpful in assessing the level of suburbanization or urban-sprawl. Suburbanization does not necessarily have to be related to a shift of residents from central urban areas to areas beyond the city limits. This process can also involve settlement on the outskirts of a city. Generally, these two types of suburbanization processes are related. In Lublin, both of these types of suburbanization are visible, as shown by the analysis of sales of undeveloped real estate with the single-family housing designation. Clearly, an evaluation of suburbanization processes should not overlook other factors. One of them is mentioned spatial policy.

The spatial referencing of the database using GIS systems made the data more legible, thus facilitating the exploration of the real estate market. Also, the application of cartographic methods of data representation enabled an adequate and thorough analysis of the data.

\section{Acknowledgements}

Publication is funded by the Polish National Agency for Academic Exchange under the International Academic Partnerships Programme from the project „Organization of the $9^{\text {th }}$ International Scientific and Technical Conference entitled Environmental Engineering, Photogrammetry, Geoinformatics - Modern Technologies and Development Perspectives".

\section{References}

1. M. Fuhrmann, Cities, 94, 286-295 (2019).

2. C. Kowalczyk, M. Nowak, S. Źróbek, Land Use Policy, 86, 229-237 (2019).

3. P. Kilgarriff, M. Charlton, R. Foley, C. O'Donoghue, Journal of Housing Economics, 43, 118-130 (2019).

4. L. Kauškale, I. Geipele, Procedia Engineering, 172, 505-512 (2017).

5. P. Cichociński, Studia i Materiały Towarzystwa Naukowego Nieruchomości, 17(2), 65-76 (2009).

6. J. Brzezicka, R. Wiśniewski, Land Use Policy, 55, 166-181 (2016).

7. P. Pochwatka, U. Litwin, T. Teterycz, A. Bitner, Cartographic Visualization in The Real Estate Market Investigation with the Use of GIS Tools, 2017 Baltic Geodetic Congress (BGC Geomatics), Gdansk, 105-109 (2017).

8. E. Kucharska-Stasiak, M. Załęczna, K. Żelazowski, Wpływ procesu integracji Polski z Unią Europejską na rozwój rynków nieruchomości (Integration with the European Union - influence on the development of the real estate markets), Wydawnictwo Uniwersytetu Łódzkiego, Łódź (in Polish) (2012).

9. M. Li, Z. Bao, T. Sellis, S. Yan, R. Zhang, Journal of Visual Languages and Computing, 45, 1-16 (2018).

10. H. Gawron, Analiza rynku nieruchomości (Analysis of the real estate market), Wydawnictwo Uniwersytetu Ekonomicznego w Poznaniu, Poznań (in Polish) (2011).

11. B. Grum, D. Kobe Govekar, Procedia Economics and Finance, 39, 597-604 (2016).

12. T. Kauko, P. Hooimeijer, J. Hakfoort, Houseing Studies, 17, 875-894 (2002).

13. E. Kucharska-Stasiak, B. Schneider, M. Załęczna, Methodology for Local and Regional Real Estate Market, Wydawnictwo Uniwersytetu Łódzkiego, Łódź (in Polish) (2009).

14. R.K. Pace, S. Zhu, Journal of Housing Economics, 43, 72-82 (2019).

15. W. Liang, M. Lu, H. Zhang, Journal of Housing Economics, 33, 70-81 (2016).

16. E. Zysk, A. Źróbek-Różańska, Real Estate Management and Valuation, 24(4), 59-69 (2016).

17. G. Wijburg, Geoforum, 100, 209-219 (2019).

18. K. Jóźwiakowski, D. Podbrozna, K. Kopczacka, M. Marzec, A. Kowalczyk-Juśko, P. Pochwatka, A. 
Listosz, A. Malik, Journal of Ecological Engineering, 18(6), 192-199 (2017).

19. K. Jóźwiakowski D. Podbrozna, K. Kopczacka, M. Jaguś, M. Marzec, A. Listosz, P. Pochwatka, A. Kowalczyk-Juśko, A. Malik, Journal of Ecological Engineering, 19(2), 255-262 (2018).

20. A. Micek, M. Marzec, K. Jóźwiakowska, P. Pochwatka, Journal of Ecological Engineering, 19(5), 107-115 (2018).

21. K. Nieścioruk, Bulletin of Geography, 22, 81-95 (2013).

22. K. Nieścioruk, Bulletin of Geography, 31, 73-86 (2016).

23. BIP 2019, https://bip.lublin.eu/informacjapubliczna/dane-demograficzne/dane-demograficznestan-na-dzien-30-09-2019r-,40,22886,2.html

24. M. Markowski, Rozwój przestrzenny Lublina w XX wieku (The Spatial Development of Lublin in the Twentieth Century), Rocznik Lubelski Tom 38, Polskie Towarzystwo Historyczne, Lublin (in Polish) (2012).

25. K. Nieścioruk, Rozwój terytorialny Lublina - ujęcie historyczne (Territorial development of Lublin - a historical view, master thesis), Zakład Kartografii, Uniwersytet Marii Curie-Skłodowskiej w Lublinie, Lublin (in Polish) (2002).

26. D. Kociuba, Annales Universitatis Mariae CurieSkłodowska, Vol LXII/15, Sectio B, 305-326 (in Polish) (2007). 